\title{
Um papa do fim do mundo, uma teologia do terceiro mundo e uma Igreja para todo mundo
}

\author{
Orientador: Cesar Augusto Kuzma \\ Mestranda: Beatriz Maria Gross \\ Área de Concentração: Teologia Sistemático-Pastoral \\ Linha de Pesquisa: Fé e Cultura
}

"Um papa do fim do mundo, uma teologia do terceiro mundo e uma Igreja para todo o mundo" propõe uma análise da possibilidade para a Igreja do terceiro milênio a partir da eleição de um argentino vindo do fim do mundo como papa, e de sua experiência como sacerdote pós-conciliar. Nesse lugar do qual veio o papa Francisco, as terras da América Latina e do Caribe, também se produziu uma singular teologia ao final do século XX, que refletia as condições sociais, políticas, econômicas e culturais do povo latino-americano: a teologia da libertação. Esta dissertação apresenta uma biografia de Jorge Mario Bergoglio, um panorama histórico da Argentina que recebeu os imigrantes europeus no início do século XX, entre eles a família do futuro papa, e o impacto da escolha do nome Francisco. Na sequência, traz a história do desenvolvimento da teologia no Novo Mundo, que culminou com o surgimento da teologia da libertação, suas principais ideias e, por fim, analisa as propostas eclesiológicas do papa Francisco apresentadas na Evangelii Gaudium, em consonância com as principais temáticas da teologia da libertação, sua defesa dos pobres, explorados e desfavorecidos como projeto de missão da Igreja e, principalmente, sua percepção da necessidade de atualizar a Igreja (retomando as originais propostas do Concílio Vaticano II especialmente concretizadas em Medellín), para um mundo que hoje se descortina plural e crítico.

Palavras-chave: Papa Francisco. Teologia da libertação. Igreja. 